Check for updates

Cite this: RSC Adv., 2018, 8, 37077

Received 17th August 2018

Accepted 27th October 2018

DOI: $10.1039 / c 8 r a 06887 a$

rsc.li/rsc-advances

\section{Biocompatible zwitterionic copolymer-stabilized magnetite nanoparticles: a simple one-pot synthesis, antifouling properties and biomagnetic separation $\dagger$}

\author{
Supannika Boonjamnian, ${ }^{a}$ Thanida Trakulsujaritchok, ${ }^{\text {bc }}$ Klaokwan Srisook, ${ }^{\text {cd }}$ \\ Voravee P. Hoven (D) ef and Piyaporn Na Nongkhai (D) *abc
}

\begin{abstract}
A simple one-pot synthesis of biocompatible and antifouling magnetite nanoparticles $\left(\mathrm{Fe}_{3} \mathrm{O}_{4} \mathrm{NPs}\right.$ ) was developed. The process involves co-precipitation and in situ coating of zwitterionic copolymer poly [(methacrylic acid)-co-(2-methacryloyloxyethyl phosphorylcholine)] (PMAMPC). The influence of onestep and two-step coating methods on the performance of modified $\mathrm{Fe}_{3} \mathrm{O}_{4} \mathrm{NP}$ was investigated. The PMAMPC- $\mathrm{Fe}_{3} \mathrm{O}_{4} \mathrm{NP}$ with a narrow particle size distribution obtained from the two-step approach were highly stable in aqueous media within a wide range of $\mathrm{pH}$. The particles exhibited superparamagnetic behavior with high saturation magnetization values so that they could be easily separated from solution by a magnet. Their antifouling characteristics against 2 selected proteins, lysozyme (LYZ) and bovine serum albumin (BSA), as a function of copolymer molecular weight and composition were also evaluated. Moreover, taking advantage of having carboxyl groups in the coated copolymer, the PMAMPC- $\mathrm{Fe}_{3} \mathrm{O}_{4} \mathrm{NP}$ were conjugated with a model biomolecular probe, biotin. The biotin-immobilized PMAMPC- $\mathrm{Fe}_{3} \mathrm{O}_{4} \mathrm{NP}$ were then tested for their specific capturing of a target molecule, streptavidin. The results have demonstrated the potential of PMAMPC- $\mathrm{Fe}_{3} \mathrm{O}_{4} \mathrm{NP}$ prepared by the two-step in situ coating method for probe immobilization and subsequent biomagnetic separation of target molecules. The fact that the developed functionalizable magnetite nanoparticles are biocompatible and antifouling also opens up the possibility of their use in other biomedical-relevant applications.
\end{abstract}

\section{Introduction}

Superparamagnetic iron oxide nanoparticles, especially magnetite nanoparticles $\left(\mathrm{Fe}_{3} \mathrm{O}_{4} \mathrm{NPs}\right)$, have been widely used in a variety of biomedical applications, such as magnetic resonance imaging (MRI), ${ }^{1,2}$ magnetic separation,,$^{3-5}$ drug delivery, ${ }^{6,7}$ and biosensors. ${ }^{8-10}$ These applications require particles that exhibit superparamagnetic behaviour at room temperature and have high magnetization values. To be applied for biological

${ }^{a}$ Sensor Innovation Research Unit (SIRU), Burapha University, Muang, Chonburi 20131, Thailand.E-mail: piyapornn@buu.ac.th

${ }^{b}$ Department of Chemistry, Faculty of Science, Burapha University, Muang, Chonburi 20131, Thailand

${ }^{c}$ Center of Excellence for Innovation in Chemistry, Burapha University, Muang, Chonburi 20131, Thailand

${ }^{d}$ Department of Biochemistry, Faculty of Science, Burapha University, Muang, Chonburi 20131, Thailand

${ }^{e}$ Department of Chemistry, Faculty of Science, Chulalongkorn University, Phayathai Road, Pathumwan, Bangkok 10330, Thailand

${ }^{f}$ Center of Excellence in Materials and Biointerfaces, Chulalongkorn University, Phayathai Road, Pathumwan, Bangkok 10330, Thailand

$\dagger$ Electronic supplementary information (ESI) available. See DOI: $10.1039 /$ c8ra06887a and medical diagnosis, the magnetite nanoparticles must be stable in water at neutral $\mathrm{pH}$ and under physiological conditions and should not non-specifically adsorb proteins and other biological components. Coating with polymers having antifouling characteristics has been recognized as an efficient approach that can not only offer antifouling properties to but also enhance colloidal stability of the $\mathrm{Fe}_{3} \mathrm{O}_{4} \mathrm{NPs}^{1{ }^{11-20}}$ In principle, the polymer-stabilized $\mathrm{Fe}_{3} \mathrm{O}_{4} \mathrm{NPs}$ can be prepared by either a one-step method where in situ formation of the nanoparticles and the polymer coating takes place concurrently, or a two-step method where the nanoparticles are firstly formed and the polymer is then coated thereafter.

Poly(ethylene glycol) (PEG) and its derivatives have been recognized as typical hydrophilic polymers that are extensively used to modify the $\mathrm{Fe}_{3} \mathrm{O}_{4} \mathrm{NPs}$ for biomedical applications due to their protein resistant properties. ${ }^{12-14}$ Besides PEG, poly(2methacryloyloxyethyl phosphorylcholine) (PMPC), a hydrophilic zwitterionic polymer which contains positively and negatively charged moieties within the same structure, has also received much attention as an alternative antifouling polymeric stabilizer for $\mathrm{Fe}_{3} \mathrm{O}_{4} \mathrm{NPs}^{15-20}$ It has been demonstrated that PMPC can be tethered to the surface of $\mathrm{Fe}_{3} \mathrm{O}_{4} \mathrm{NPs}$ by surface- 
initiated atom transfer radical polymerization (SI-ATRP). ${ }^{\mathbf{1 6}-19}$ This "grafting from" method required a two-step approach: surface immobilization of ATRP initiator and then PMPC formation. A simple one step in situ formation of PMPCstabilized $\mathrm{Fe}_{3} \mathrm{O}_{4} \mathrm{NPs}$ whereby co-precipitation of ferric and ferrous salts happens simultaneously with the coating of PMPC is not possible due to a lack of anchoring group with strong affinity in the PMPC structure to bind with the surface of $\mathrm{Fe}_{3}$ $\mathrm{O}_{4}$ NPs. Armes and co-workers ${ }^{20}$ have shown that such limitation can be overcome by using a double hydrophilic block copolymer of PMPC and poly(glycerol monomethacrylate) (PGMA). PGMA would act as an absorbing block via a five-membered cyclic chelation between the 1,2-diol moieties in the side chain of PGMA and Fe atoms on the surface of $\mathrm{Fe}_{3} \mathrm{O}_{4} \mathrm{NPs}^{12,13} \mathrm{~A}$ similar strategy has recently been reported by Zheng and co-workers, ${ }^{15}$ using a random copolymer of poly[(methacrylic acid)-co-(2methacryloyloxyethyl phosphorylcholine)] (PMAMPC) synthesized by reversible addition fragmentation chain transfer (RAFT) polymerization. The PMAMPC-coated $\mathrm{Fe}_{3} \mathrm{O}_{4} \mathrm{NPs}$ were readily synthesized by coprecipitation of ferric and ferrous salts in the presence of PMAMPC and ammonium hydroxide. The carboxylate ions of the methacrylic acid (MA) units were capable of chelating to $\mathrm{Fe}$ atoms during the $\mathrm{Fe}_{3} \mathrm{O}_{4} \mathrm{NPs}$ formation, while the PMPC segment conferred colloidal stability and biocompatibility. Although one-step in situ coating of PMAMPC copolymer on $\mathrm{Fe}_{3} \mathrm{O}_{4} \mathrm{NPs}$ was successful, the values of saturation magnetization $\left(M_{\mathrm{s}}\right)$ for the PMAMPC-modified $\mathrm{Fe}_{3} \mathrm{O}_{4} \mathrm{NPs}$ were extremely low. It was difficult to separate $\mathrm{Fe}_{3} \mathrm{O}_{4} \mathrm{NPs}$ having low $M_{\mathrm{s}}$ values from solution by applying a magnetic field thus centrifugation must be applied for separation.

Previously, PMPC-based copolymers have been introduced by our group as antifouling and functional polymeric layer for biosensing probe conjugation., ${ }^{\mathbf{2 1 2 2}}$ Thiol-terminated poly [(methacrylic acid)-co-(2-methacryloyloxyethyl phosphorylcholine)] (PMAMPC-SH) was tethered to gold-coated substrate prior to conjugation with biotin employing carboxyl groups from the MA units. By using surface plasmon resonance (SPR), highly efficient detection of a specific target analyte, avidin, in diluted blood plasma was successful owning to the ability to resist nonspecific protein adsorption of the PMPC units. ${ }^{21}$

Although the success in preparation of magnetic iron oxide nanoparticles coated with PMPC-based polymer has been continuously reported, ${ }^{\mathbf{1 5 - 2 0}}$ there are several problems associated with the complex synthesis methodologies and the inferior magnetic properties of the synthesized nanoparticles that limit their biomedical-relevant applications. Therefore, much attention is now focused on not only the development of simple methods to incorporate the functional polymeric layer on the surface of the magnetite nanoparticles but also providing the desirable magnetic properties. Herein, we reported a simple coating method, called a two-step in situ coating, where the $\mathrm{Fe}_{3} \mathrm{O}_{4} \mathrm{NPs}$ were firstly grown by co-precipitation and then PMAMPC was directly added to anchor onto the $\mathrm{Fe}_{3} \mathrm{O}_{4} \mathrm{NPs}$, of which the formation of the nanoparticles and the polymer coating can be done in a "one-pot" system. Unlike the PMAMPC$\mathrm{Fe}_{3} \mathrm{O}_{4} \mathrm{NPs}$ prepared via the one-step in situ coating of PMAMPC as previously reported by others, ${ }^{\mathbf{1 5}}$ the $\mathrm{PMAMPC}-\mathrm{Fe}_{3} \mathrm{O}_{4} \mathrm{NPs}$ prepared by the two-step in situ coating in this work possessed a higher saturation magnetization value so that they can be easily separated under an external magnetic field without the requirement for centrifugation. To the best of our knowledge, this is the first report on comparative studies between the onestep and two-step in situ coating methods for the preparation of PMAMPC- $\mathrm{Fe}_{3} \mathrm{O}_{4} \mathrm{NPs}$ and their properties. Additionally, the application of PMAMPC- $\mathrm{Fe}_{3} \mathrm{O}_{4} \mathrm{NPs}$ for biospecific separation was also demonstrated. Biotin conjugated to the carboxyl groups from MA units in the copolymer coated on PMAMPC$\mathrm{Fe}_{3} \mathrm{O}_{4} \mathrm{NPs}$ were specifically capable of capturing the target molecules, streptavidin, as evaluated in comparison with the non-target molecule, bovine serum albumin (BSA).

\section{Materials and methods}

\section{Chemicals}

Ferrous chloride tetrahydrate $\left(\mathrm{FeCl}_{2} \cdot 4 \mathrm{H}_{2} \mathrm{O}\right)$, ferric chloride hexahydrate $\left(\mathrm{FeCl}_{3} \cdot 6 \mathrm{H}_{2} \mathrm{O}\right)$, ammonium hydroxide solution $\left(\mathrm{NH}_{4} \mathrm{OH}, 28 \% \mathrm{w} / \mathrm{v}\right)$ phosphate buffer saline (PBS), lysozyme (LYS), bovine serum albumin (BSA), 1-(3-(dimethylamino) propyl)-3-ethylcarbodiimide hydrochloride (EDC), $N$-hydroxysuccinimide (NHS), and streptavidin were purchased from Sigma-Aldrich (Singapore). Amine- $\mathrm{PEG}_{2}$-biotin $\left(\mathrm{NH}_{2}\right.$-biotin) was purchased from Thermo Fisher Scientific (USA). Bio-rad dye reagent concentrate for Bradford protein assay was purchased from BIO-RAD (USA). 3-(4,5-Dimethylthiazol-2-yl)-2,5diphenyltetrazolium bromide (MTT) and Dulbecco's Modified Eagle's medium (DMEM) were purchased from Sigma Chemical (USA). Fetal bovine serum (FBS) was purchased from Invitrogen/ Gibco (USA). A series of poly[(methacrylic acid)-co-(2-methacryloyloxyethyl phosphorylcholine)] having varied copolymer composition $\left(\mathrm{PMA}_{x} \mathrm{MPC}_{y}\right)$ and molecular weight were synthesized by RAFT polymerization following the reported procedure. ${ }^{21}$ The characteristics of the synthesized copolymers are displayed in Fig. S1 and Table S1 of the ESI. $\dagger$

\section{Synthesis of PMAMPC-Fe $\mathrm{O}_{3} \mathrm{O}_{4} \mathrm{NPs}$}

$\mathrm{Fe}_{3} \mathrm{O}_{4} \mathrm{NPs}$ were prepared and coated with PMAMPC using two in situ methods: one-step and two-step methods. In the case of the two-step method, the $\mathrm{Fe}_{3} \mathrm{O}_{4}$ NPs were firstly formed by chemical co-precipitation of ferrous/ferric ions in alkaline medium and then PMAMPC solution was directly added to $\mathrm{Fe}_{3} \mathrm{O}_{4} \mathrm{NPS}$ suspension providing a coating of PMAMPC on $\mathrm{Fe}_{3} \mathrm{O}_{4} \mathrm{NPs}$ through chelating bond. Typically, $\mathrm{FeCl}_{3} \cdot 6 \mathrm{H}_{2} \mathrm{O}(298 \mathrm{mg}, 1.10$ $\mathrm{mmol})$ and $\mathrm{FeCl}_{2} \cdot 4 \mathrm{H}_{2} \mathrm{O}(109 \mathrm{mg}, 0.55 \mathrm{mmol})$ were dissolved in $20 \mathrm{~mL}$ DI water at room temperature. After the salt was completely dissolved, the mixture was added to a flask under nitrogen atmosphere at $60{ }^{\circ} \mathrm{C}$ and mechanically stirred at $750 \mathrm{rpm}$ for $30 \mathrm{~min} .6 \mathrm{~mL}$ of aqueous ammonia solution $(28 \%$ $\mathrm{w} / \mathrm{v}$ ) was slowly added and the solution color changed from orange to black. The colloidal mixture was continuously stirred for another hour. Subsequently, $40 \mathrm{mg}$ of PMAMPC (PMA ${ }_{37}$ $\left.\mathrm{MPC}_{63}, 54.5 \mathrm{kDa}\right)$ corresponding to $68.8 \mu \mathrm{mol}$ of carboxyl groups $(\mathrm{COOH})$ was directly added to the black colloidal mixture. The mixture was stirred for $1 \mathrm{~h}$ and cooled to room 
temperature. The PMAMPC-Fe ${ }_{3} \mathrm{O}_{4} \mathrm{NPs}$ obtained were separated by a magnet and washed with DI water several times to remove unreacted chemicals. The PMAMPC- $\mathrm{Fe}_{3} \mathrm{O}_{4} \mathrm{NPs}$ were dispersed in distilled water and stored as aqueous colloidal suspensions. The amounts of the $\mathrm{PMA}_{37} \mathrm{MPC}_{63}$ in the feed solution was 10, 20 and $40 \mathrm{mg}$. Copolymers with varied composition $\left(\mathrm{PMA}_{21} \mathrm{MPC}_{79}\right.$, $\mathrm{PMA}_{37} \mathrm{MPC}_{63}$ and $\mathrm{PMA}_{66} \mathrm{MPC}_{34}$ ) and molecular weight (12.0, 25.9 and $54.5 \mathrm{kDa}$ ) were also used for the preparation of PMAMPC- $\mathrm{Fe}_{3} \mathrm{O}_{4}$ NPs in order to investigate the effect of copolymer composition and molecular weight on antifouling properties.

In the case of the one-step method, the PMAMPC- $\mathrm{Fe}_{3} \mathrm{O}_{4} \mathrm{NPs}$ were synthesized by a chemical co-precipitation of ferrous/ ferric ions in the presence of PMAMPC $\left(\mathrm{PMA}_{37} \mathrm{MPC}_{63}, 54.5\right.$ $\mathrm{kDa})$ in alkaline medium. $\mathrm{FeCl}_{3} \cdot 6 \mathrm{H}_{2} \mathrm{O}(298 \mathrm{mg}, 1.10 \mathrm{mmol})$, $\mathrm{FeCl}_{2} \cdot 4 \mathrm{H}_{2} \mathrm{O}$ (109 mg, $0.55 \mathrm{mmol}$ ) and PMAMPC (40 mg, 68.8 $\mu \mathrm{mol}$ of $\mathrm{COOH}$ ) were dissolved in $20 \mathrm{~mL}$ DI water at room temperature. The $\mathrm{Fe}_{3} \mathrm{O}_{4}$ NPs were formed and simultaneously chelated with the carboxylate ions in PMAMPC after the addition of $6 \mathrm{~mL}$ of aqueous ammonia solution $(28 \% \mathrm{w} / \mathrm{v})$ under nitrogen atmosphere at $60{ }^{\circ} \mathrm{C}$. The mixture was stirred at $750 \mathrm{rpm}$ for $2 \mathrm{~h}$ and cooled to room temperature. The PMAMPC- $\mathrm{Fe}_{3} \mathrm{O}_{4} \mathrm{NPs}$ obtained were separated by a magnet and washed with DI water several times. The PMAMPC- $\mathrm{Fe}_{3} \mathrm{O}_{4} \mathrm{NP}$ were dispersed in distilled water and stored as aqueous colloidal suspensions. Uncoated $\mathrm{Fe}_{3} \mathrm{O}_{4}$ NPs were also synthesized by the same method in the absence of PMAMPC.

\section{Characterization}

The morphology, size and size distribution of the $\mathrm{Fe}_{3} \mathrm{O}_{4} \mathrm{NPs}$ were evaluated using transmission electron microscopy (TEM, Philips TECNAI 20). Fourier transform infrared (FT-IR) spectra were recorded by PERKIN ELMER using a KBr disk method. The amount of polymer content was determined by thermogravimetric analysis (TGA, MettlerToledo TGA/SDTA $851^{\mathrm{e}}$ ). The weight loss of the dried samples was monitored under nitrogen atmosphere at temperatures ranging from 25 to $800{ }^{\circ} \mathrm{C}$ with a heating rate of $10{ }^{\circ} \mathrm{C} \mathrm{min}{ }^{-1}$. The crystalline phase was studied by X-ray diffraction (XRD, Bruker AXS Model D8 Discover). The hydrodynamic diameter and zeta potential were measured by dynamic light scattering (DLS) using a Malvern Nano ZSP instrument (UK) at room temperature at a scattering angle of $90^{\circ}$

\section{Colloidal stability study}

Colloidal stability of the unmodified $\mathrm{Fe}_{3} \mathrm{O}_{4}$ NPs and PMAMPC$\mathrm{Fe}_{3} \mathrm{O}_{4} \mathrm{NPs}$ suspensions $\left(0.1 \mathrm{mg} \mathrm{mL} \mathrm{mL}^{-1}\right)$ were visually monitored in buffer solutions having $\mathrm{pH}$ in the range 1-11 in the absence of external magnetic field. The quantitative measure of colloidal stability by DLS has been performed.

\section{Protein adsorption study}

To test the antifouling properties of the PMAMPC- $\mathrm{Fe}_{3} \mathrm{O}_{4} \mathrm{NPs}$, LYZ and BSA were used as models for positively charged and negatively charged proteins, respectively. The protein was dissolved in PBS (10 mM, pH 7.4). $500 \mu \mathrm{L}$ of $1 \mathrm{mg} \mathrm{mL}{ }^{-1}$ protein solution was added to a $500 \mu \mathrm{L}$ colloidal solution of PMAMPC$\mathrm{Fe}_{3} \mathrm{O}_{4} \mathrm{NPs}\left(2 \mathrm{mg} \mathrm{mL}{ }^{-1}\right)$ and incubated under gentle shaking at room temperature for $30 \mathrm{~min}$. Then, the particles were magnetically separated. Supernatant was collected and analyzed for the remaining protein by the Bradford protein assay. The amount of adsorbed protein on the PMAMPC- $\mathrm{Fe}_{3}$ $\mathrm{O}_{4} \mathrm{NPs}\left(q_{\mathrm{e}}, \mathrm{mg} \mathrm{g}^{-1}\right)$ was calculated using eqn (1).

$$
q_{\mathrm{e}}=\frac{\left(C_{0}-C_{\mathrm{e}}\right) v}{m}
$$

when $C_{0}$ and $C_{\mathrm{e}}$ are the protein concentrations before and after adsorption ( $\left.\mathrm{mg} \mathrm{mL}^{-1}\right), v$ is the volume of the aqueous phase $(\mathrm{mL})$, and $m$ is the weight of the nanoparticles $(\mathrm{g})$.

\section{Evaluation of cell viability in the presence of magnetite nanoparticles}

An MTT assay was used to evaluate the cytotoxicity of the unmodified $\mathrm{Fe}_{3} \mathrm{O}_{4} \mathrm{NPs}$ and PMAMPC-Fe ${ }_{3} \mathrm{O}_{4} \mathrm{NPs}$. Human umbilical vein endothelial cell line (EA.Hy926) obtained from the American-type culture collection (ATCC) were cultured in Dulbecco's Modified Eagle's Medium (DMEM) containing 10\% heat-inactivated FBS. The cells were plated into a 24 -well plate $\left(1.5 \times 10^{5}\right.$ cells per well). After an overnight incubation, media containing various concentrations of the nanoparticles $(0.0625$, $0.125,0.25 \mathrm{mg} \mathrm{mL}^{-1}$ ) were added to wells for $24 \mathrm{~h}$. The nanoparticles were removed from the cells and then the morphology of cells before and after culturing with the nanoparticles were observed using a Olympus inverse phase contrast microscope (OLYMPUS IX70, Japan) equipped with an objective (LCAch 20X/ 0.04 phC, Olympus, Japan) of $20 \times$ magnification. MTT solution (10 $\mu \mathrm{L}, 5 \mathrm{mg} \mathrm{mL}{ }^{-1}$ in PBS) was added into each well for $2 \mathrm{~h}$ before aspiration of the solution. Dimethyl sulfoxide $(500 \mu \mathrm{L})$ was added into each well to solubilize the blue formazan crystal product. Subsequently, the absorbance was measured at the wavelength of $550 \mathrm{~nm}$ using a microplate reader (Molecular Device, USA). The amount of formazan was proportional to the number of functional mitochondria in viable cells. All experiments were performed in triplicate and cells in culture media without the nanoparticles were used as a control. Percentage of cell viability was expressed as absorbance of treated well/ absorbance of control well $\times 100 .{ }^{23,24}$ Data were expressed as means \pm S.D. $(n=3)$.

\section{Immobilization of biotin onto PMAMPC- $\mathrm{Fe}_{3} \mathrm{O}_{4} \mathrm{NPs}$}

The carboxyl groups of the coated PMAMPC were first activated by an aqueous solution of EDC and NHS. A $100 \mu \mathrm{L}$ of fresh mixed solution of EDC $\left(50 \mathrm{mg} \mathrm{mL}{ }^{-1}\right)$ and NHS $\left(50 \mathrm{mg} \mathrm{mL}^{-1}\right)$ was added to $500 \mu \mathrm{L}$ of aqueous suspension of PMAMPC-Fe $3^{-}$ $\mathrm{O}_{4} \mathrm{NPs}\left(10 \mathrm{mg} \mathrm{mL}{ }^{-1}\right)$ for $30 \mathrm{~min}$. The activated PMAMPC-Fe $3^{-}$ $\mathrm{O}_{4}$ NPs were separated from the solution by a magnet and washed with DI water. Then, the activated PMAMPC- $\mathrm{Fe}_{3} \mathrm{O}_{4} \mathrm{NPs}$ were re-suspended in $500 \mu \mathrm{L}$ of $\mathrm{NH}_{2}$-biotin solution $(10 \mathrm{mg}$ $\mathrm{mL}^{-1}$ ) in DI water and incubated at room temperature overnight. After the incubation step, the nanoparticles were separated with a magnet, washed and re-suspended in DI water. 


\section{Biospecific separation of biotinylated PMAMPC-Fe ${ }_{3} \mathrm{O}_{4} \mathrm{NP}$}

$100 \mu \mathrm{L}$ of biotinylated PMAMPC-Fe ${ }_{3} \mathrm{O}_{4} \mathrm{NPs}\left(1 \mathrm{mg} \mathrm{mL}{ }^{-1}\right)$ was added to $100 \mu \mathrm{L}$ of streptavidin $\left(1 \mathrm{mg} \mathrm{mL}^{-1}\right)$. The mixture was mixed by vortex and incubated by shaking vigorously at room temperature for $45 \mathrm{~min}$. By a magnetic separation, the supernatant solution was collected and used to determine the content of un-captured streptavidin by UV/Vis spectrophotometer. The capture efficiency (\%) was calculated using eqn (2).

$$
\text { Capture efficiency }(\%)=\frac{\left(C_{0}-C_{\mathrm{e}}\right) 100}{C_{0}}
$$

when $C_{0}$ and $C_{\mathrm{e}}$ are the streptavidin concentration in solution before and after magnetic separation expressed as the absorbance value at $282 \mathrm{~nm}$, respectively. A similar procedure was also performed for BSA separation.

\section{Results and discussion}

\section{Synthesis and characterization of PMAMPC-coated $\mathrm{Fe}_{3} \mathrm{O}_{4} \mathrm{NPS}$}

PMAMPC- $\mathrm{Fe}_{3} \mathrm{O}_{4}$ NPs were synthesized via two different in situ methods, the one-step and two-step methods (Scheme 1). FT-IR analysis can be used to confirm the success of PMAMPC anchoring on the $\mathrm{Fe}_{3} \mathrm{O}_{4} \mathrm{NPs}$ surface. As demonstrated in Fig. 1, a strong peak appearing at $580 \mathrm{~cm}^{-1}$ corresponded to the characteristic band of $\mathrm{Fe}-\mathrm{O}$ stretching vibration mode of $\mathrm{Fe}_{3}$ $\mathrm{O}_{4}$ NPs. The peaks at $1630 \mathrm{~cm}^{-1}$ could be assigned to the stretching vibration of the hydroxyl group on the surface of the $\mathrm{Fe}_{3} \mathrm{O}_{4} \mathrm{NPs}^{25,26}$ The characteristic bands of PMAMPC showed $\mathrm{C}=$ $\mathrm{O}, \mathrm{P}-\mathrm{O}$ and $\mathrm{N}^{+}\left(\mathrm{CH}_{3}\right)_{3}$ stretching vibration at 1710, 1094 and $975 \mathrm{~cm}^{-1}$, respectively. The presence of the chelating bond was observed at $1589 \mathrm{~cm}^{-1}$ and $1412 \mathrm{~cm}^{-1}$ which can be assigned to the asymmetric and symmetric $\mathrm{C}-\mathrm{O}$ stretching modes of carboxylate groups. Moreover, the wavenumber separation $(\Delta)$, between the asymmetric and symmetric $\mathrm{C}-\mathrm{O}$ stretching of carboxylate bands can be used to distinguish the coordination

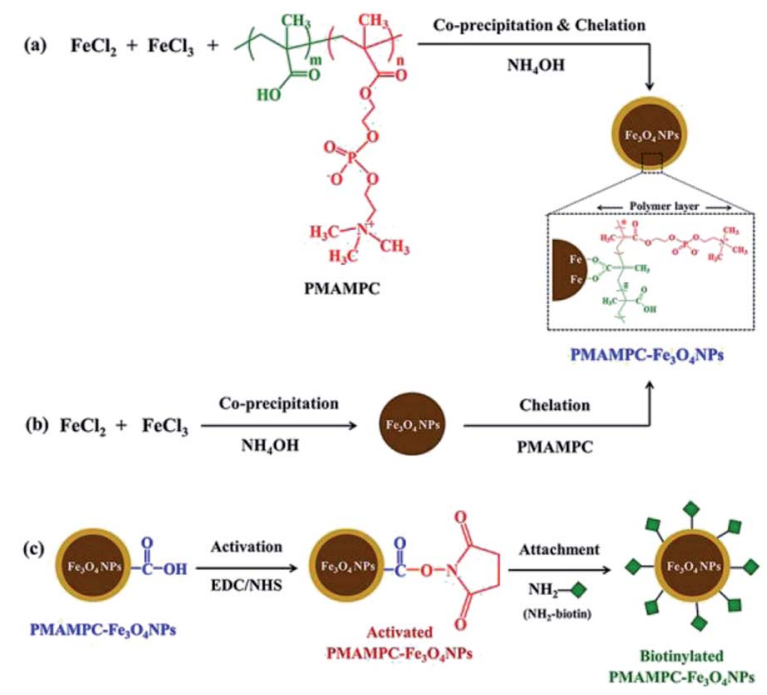

Scheme 1 Synthesis of PMAMPC- $\mathrm{Fe}_{3} \mathrm{O}_{4} \mathrm{NPs}$ by (a) one-step and (b) two-step methods and (c) immobilization of $\mathrm{NH}_{2}$-biotin onto PMAMPC $-\mathrm{Fe}_{3} \mathrm{O}_{4} \mathrm{NPs}$.

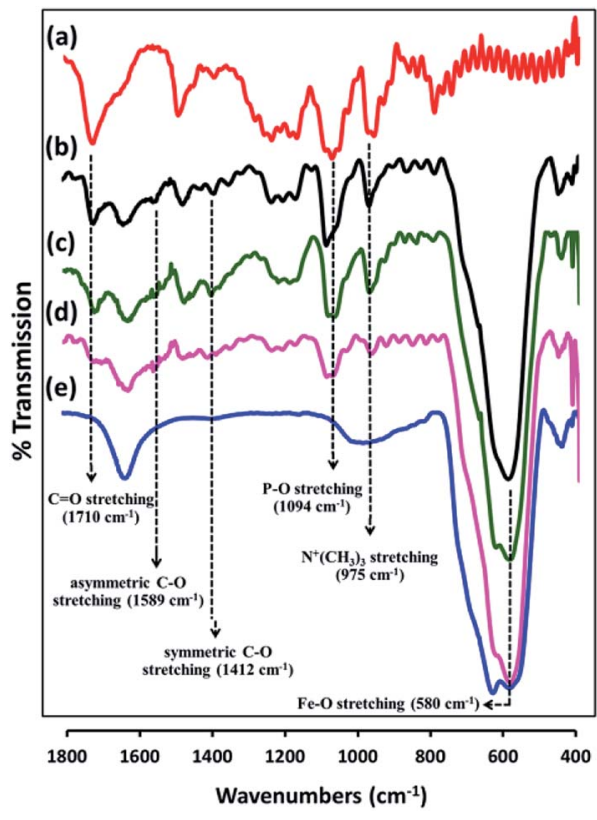

Fig. 1 FT-IR spectra of (a) PMAMPC, PMAMPC- $\mathrm{Fe}_{3} \mathrm{O}_{4} \mathrm{NPs}$ synthesized by (b) two-step method, and (c) one-step method, (d) biotinylated PMAMPC- $\mathrm{Fe}_{3} \mathrm{O}_{4} \mathrm{NPs}$, and (e) uncoated $\mathrm{Fe}_{3} \mathrm{O}_{4} \mathrm{NPs}$.

types, i.e. monodentate, bidentate and bridging complexes. ${ }^{27-30}$ The large $\Delta\left(>200 \mathrm{~cm}^{-1}\right)$ corresponds to the monodentate interaction and the small $\Delta\left(<110 \mathrm{~cm}^{-1}\right)$ is the bidentate interaction. The medium range $\Delta\left(140-200 \mathrm{~cm}^{-1}\right)$ was the bridging interaction. In this work, the $\Delta$ value is $177 \mathrm{~cm}^{-1}$ $\left(1589-1412=177 \mathrm{~cm}^{-1}\right)$ indicating that two Fe atoms chelated with two carboxylate oxygens, agreeing with the reported bonding between poly(acrylic acid) and $\mathrm{Fe}_{3} \mathrm{O}_{4} \mathrm{NPs}^{29,30}$ From the above observations, we can confirm that PMAMPC was chemically anchored on the surface of $\mathrm{Fe}_{3} \mathrm{O}_{4}$ NPs.

The amount of PMAMPC coated on the $\mathrm{Fe}_{3} \mathrm{O}_{4} \mathrm{NPs}$ can be calculated from the weight loss as determined by TGA analysis. As seen in Fig. S2 in ESI, $\dagger$ the uncoated $\mathrm{Fe}_{3} \mathrm{O}_{4} \mathrm{NPS}$ showed a major weight loss of $4 \%$ in a temperature range of $25-100{ }^{\circ} \mathrm{C}$ which should be due to loss of water. A similar magnitude of water loss from both types of PMAMPC- $\mathrm{Fe}_{3} \mathrm{O}_{4} \mathrm{NPs}$ was also found in the same temperature range. PMAMPC- $\mathrm{Fe}_{3} \mathrm{O}_{4} \mathrm{NPS}$ showed the additional weight loss between 200 and $400{ }^{\circ} \mathrm{C}$ which could be attributed to the thermal decomposition of the PMAMPC copolymer. The weight losses of 14.8 and $13.5 \%$ corresponding to $11.1 \%$ and $9.7 \%$ of PMPC content were detected for the PMAMPC- $\mathrm{Fe}_{3} \mathrm{O}_{4}$ NPs prepared by the one-step and twostep methods, respectively. The results demonstrated that using the same amount of PMAMPC copolymer in the feed, a slightly greater PMAMPC content was incorporated into the PMAMPC- $\mathrm{Fe}_{3} \mathrm{O}_{4}$ NPs prepared by the one-step method than that in the two-step method. This may be due to the less steric hindrance in one-step method where the incorporation of the polymer chain into the nanoparticles and the growth of the nanoparticles take place concurrently. The two-step method based on "grafting to" approach where the nanoparticles are firstly formed and the polymer is then coated on the nanoparticles surface therefore gives a low coating density since the 
attached polymer chains possess a steric barrier to the approaching polymer chains. So, the PMAMPC- $\mathrm{Fe}_{3} \mathrm{O}_{4} \mathrm{NPs}$ obtained from the two-step method should have a lower PMAMPC content.

Black colloidal suspensions of PMAMPC- $\mathrm{Fe}_{3} \mathrm{O}_{4} \mathrm{NPs}$ obtained from both the one-step and two-step methods showed good colloidal stability in aqueous media for up to 30 days of storage at room temperature (Fig. 2a). However, only the PMAMPC$\mathrm{Fe}_{3} \mathrm{O}_{4} \mathrm{NPs}$ prepared by the two-step method could be rapidly separated from the dispersion using an external magnetic field for $5 \mathrm{~min}$ (Fig. 2b), showing they had an excellent magnetic response. The magnetization curves measured at room temperature for the PMAMPC- $\mathrm{Fe}_{3} \mathrm{O}_{4}$ NPs prepared by the onestep and two-step methods are compared in Fig. S3, ESI. $\dagger$ There was no residual magnetism or hysteresis loop in the magnetization of both samples, suggesting the $\mathrm{Fe}_{3} \mathrm{O}_{4} \mathrm{NPs}$ produced are superparamagnetic. High saturation magnetization values of 48 and $47 \mathrm{emu} \mathrm{g}^{-1}$ were detected for the uncoated $\mathrm{Fe}_{3} \mathrm{O}_{4} \mathrm{NPs}$ and PMAMPC- $\mathrm{Fe}_{3} \mathrm{O}_{4} \mathrm{NPs}$ prepared by the two-step method. The saturation magnetization value of the PMAMPC$\mathrm{Fe}_{3} \mathrm{O}_{4} \mathrm{NPs}$ prepared by the one-step method $\left(38 \mathrm{emu} \mathrm{g}^{-1}\right)$ was lower than the other samples. This may be ascribable to the lower weight fraction of the magnetic material within the magnetic nanoparticles-polymer composite as previously reported others. ${ }^{15,18,30}$ The magnetite content of PMAMPC- $\mathrm{Fe}_{3} \mathrm{O}_{4}$ NPs prepared by the one-step method was given as a weight
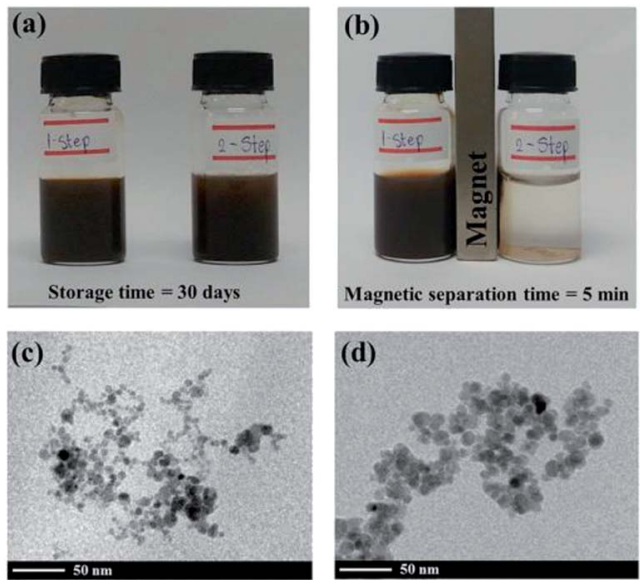

(e)

(f)
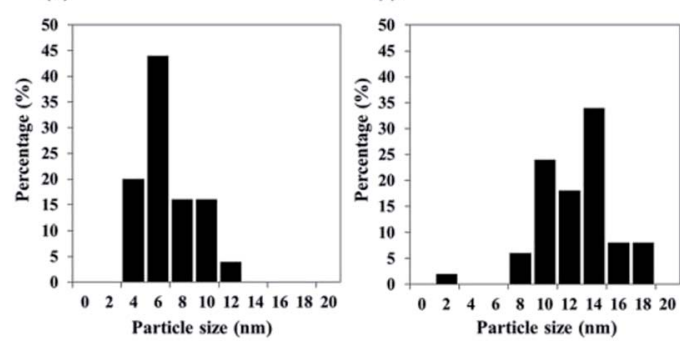

Fig. 2 Pictures of PMAMPC- $\mathrm{Fe}_{3} \mathrm{O}_{4} \mathrm{NPs}$ colloidal suspensions after 30 day of storage without an external magnetic field (a) and after exposure to an external magnetic field (b), TEM images ( $c$ and d) and particle size distribution from several TEM images $(n=100)$ (e and f) of PMAMPC- $\mathrm{Fe}_{3} \mathrm{O}_{4} \mathrm{NPs}$ prepared by the one-step ( $\mathrm{c}$ and e) and two-step (d and f) method. fraction of $88.9 \%$ which was lower than that of PMAMPC-Fe ${ }_{3}$ $\mathrm{O}_{4}$ NPs prepared by the two-step method (90.3\%). The reduction of magnetization value from 47 to $38 \mathrm{emu}^{-1}$ may not seem large. However, the difference is significant enough to possess an impact on the ability to be separated by a magnet. In fact a similar observation was reported by Majeed and co-workers ${ }^{31}$ on the pentaerythritol tetrakis 3-mercaptopropionatepolymethacrylic acid functionalized magnetic iron oxide (PTMP-PMA- $\mathrm{Fe}_{3} \mathrm{O}_{4} \mathrm{NP}_{\mathrm{S}}$ ). They have found that the particles cannot be separated by a magnet once the magnetization value was decreased from 58 to $45 \mathrm{emu} \mathrm{g}^{-1}$. The smaller mean particle size $(7.9 \pm 2.2 \mathrm{~nm})$ corresponded to the PMAMPC- $\mathrm{Fe}_{3} \mathrm{O}_{4} \mathrm{NPs}$ prepared by the two-step method $(11.7 \pm 2.8 \mathrm{~nm})$ (See Fig. $2 \mathrm{c}-\mathrm{f}$ ) may also account for the reduced magnetism..$^{28,29}$ These results support the reasons why the PMAMPC- $\mathrm{Fe}_{3} \mathrm{O}_{4} \mathrm{NPs}$ prepared by the one-step method could not be separated out of the solution by a magnet.

Fig. S4 in $\mathrm{ESI} \dagger$ shows the crystalline structure of uncoated $\mathrm{Fe}_{3} \mathrm{O}_{4} \mathrm{NPs}$ in comparison with PMAMPC- $\mathrm{Fe}_{3} \mathrm{O}_{4}$ NPs prepared by both methods. All samples showed the standard XRD pattern of magnetite nanoparticles corresponding well with previous reports. ${ }^{15,28,30}$ However, the area of the diffraction peaks of the PMAMPC- $\mathrm{Fe}_{3} \mathrm{O}_{4} \mathrm{NPs}$ prepared by the one-step method (Fig. S4c $\dagger$ ) were lower than those of the uncoated $\mathrm{Fe}_{3} \mathrm{O}_{4} \mathrm{NPs}$ and the PMAMPC- $\mathrm{Fe}_{3} \mathrm{O}_{4}$ NPs prepared by the two-step method. The peak area data are summarized in Table S2, ESI. $\dagger$ It is possible that this as a consequence of the polymer coating during nanoparticle formation interfering with the crystallization process of magnetite nanoparticles. The particle sizes of the nanoparticles were also calculated using the Scherrer formula. ${ }^{32}$ The detail of calculation is provided in Table S3, ESI. $\dagger$ The sizes of PMAMPC- $\mathrm{Fe}_{3} \mathrm{O}_{4}$ NPs prepared by the one-step and two-step method calculated from the XRD data are 9.8 and $11.4 \mathrm{~nm}$, respectively which corresponded quite well with sizes evaluated by the TEM analysis (Fig. 2).

\section{Colloidal stability of PMAMPC-Fe ${ }_{3} \mathrm{O}_{4} \mathrm{NPs}$}

The stability of PMAMPC-Fe $\mathrm{O}_{4} \mathrm{NPs}$ dispersion was determined by monitoring the settling of the nanoparticles in aqueous media. As shown in Fig. 3A, the uncoated $\mathrm{Fe}_{3} \mathrm{O}_{4} \mathrm{NPs}$ started to aggregate and settle to the bottom of vial within $15 \mathrm{~min}$ (as indicated by red arrows). It could be verified with an increase in diameter of the uncoated $\mathrm{Fe}_{3} \mathrm{O}_{4} \mathrm{NPs}$ from nanometer range to micrometer range within $15 \mathrm{~min}$ as evaluated by DLS (Fig. 3D). On the other hand, the PMAMPC-Fe ${ }_{3} \mathrm{O}_{4}$ NPs synthesized by the two in situ methods exhibited good colloidal stability with unchanged particle size, suggesting that the hydrophilic PMAMPC coating significantly improves the stability of $\mathrm{Fe}_{3} \mathrm{O}_{4}$ NPs suspension. In addition, the increase of copolymer coating on $\mathrm{Fe}_{3} \mathrm{O}_{4}$ NPs surface by increasing the PMAMPC amount in the feed solution possessed a strong impact on colloidal stability (Fig. 3A, column 3-5). The quantity of coated PMAMPC estimated from the weight loss in the temperature range 200$400{ }^{\circ} \mathrm{C}$ by TGA analysis are shown in Fig. S5, ESI. $\dagger$

Because of the dissociation of $\mathrm{COOH}$ to $\mathrm{COO}$ - groups, at $\mathrm{pH}$ $\geq 5$, the surface of PMAMPC- $\mathrm{Fe}_{3} \mathrm{O}_{4} \mathrm{NPs}$ would become positively 

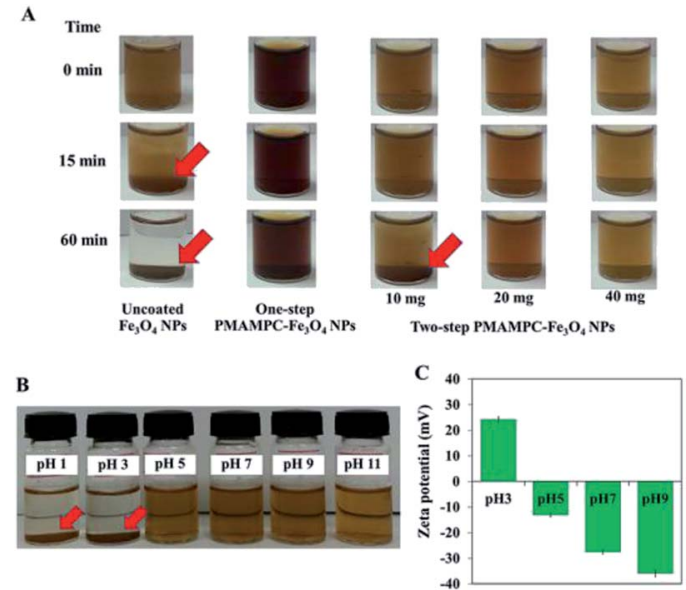

D

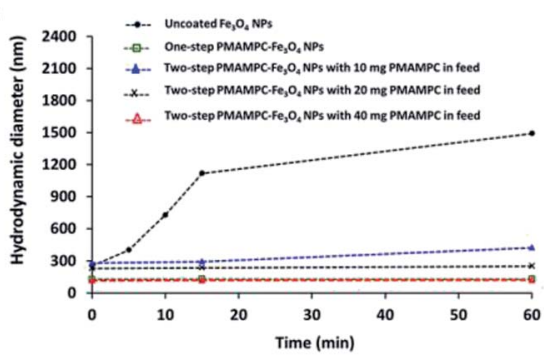

Fig. 3 (A) Pictures of uncoated $\mathrm{Fe}_{3} \mathrm{O}_{4} \mathrm{NPs}$ (column 1) and PMAMPC$\mathrm{Fe}_{3} \mathrm{O}_{4} \mathrm{NPs}$ colloidal suspensions prepared by one-step (column 2) and two-step methods using varied amounts of PMAMPC in the feed (column 3-5) in the absence of an external magnetic field, (B) PMAMPC- $\mathrm{Fe}_{3} \mathrm{O}_{4} \mathrm{NPs}$ colloidal suspensions prepared by the two-step method using $40 \mathrm{mg}$ PMAMPC in the feed, (C) their corresponding zeta potential values at different $\mathrm{pH}$ and (D) hydrodynamic diameter of PMAMPC- $\mathrm{Fe}_{3} \mathrm{O}_{4} \mathrm{NPs}$ obtained from DLS.

charged resulting in electrostatic repulsion between neighboring nanoparticles preventing aggregation. On the other hand, the $\mathrm{COOH}$ groups remain protonated at $\mathrm{pH}<5$, inducing the agglomeration of nanoparticles as can be seen in Fig. 3B. The zeta potential values shown in Fig. 3D support the assumption that colloidal stability of PMAMPC- $\mathrm{Fe}_{3} \mathrm{O}_{4} \mathrm{NPs}$ is due to $\mathrm{COOH}$ dissociation.

\section{Protein adsorption study}

The antifouling property of PMAMPC- $\mathrm{Fe}_{3} \mathrm{O}_{4} \mathrm{NPs}$ synthesized by the two-step method was determined by monitoring the adsorption of two proteins (LYS and BSA) in PBS solution (pH 7.4). As expected, the presence of PMAMPC on the surface of PMAMPC- $\mathrm{Fe}_{3} \mathrm{O}_{4} \mathrm{NPs}$ resulted in low adsorption of both LYS and BSA as compared with the uncoated $\mathrm{Fe}_{3} \mathrm{O}_{4} \mathrm{NPs}$ (Fig. 4). Under the test conditions in the PBS solution (pH 7.4, $10 \mathrm{mM}$ ), BSA (pI $=4.8$ ) would be negatively charged whereas lysozyme $(\mathrm{pI}=12)$ would be positively charged. The ability to resist protein adsorption is concentration-dependent. In other words, the amount of adsorbed protein decreased with increasing PMAMPC amount introduced to the feed solution during the one-pot synthesis (Fig. 4a). This coincides with the fact that the high amount of PMAMPC contained a greater number of hydrophilic MPC units on the surface of $\mathrm{Fe}_{3} \mathrm{O}_{4} \mathrm{NPs}$, resulting in more effective suppression of protein adsorption. A similar

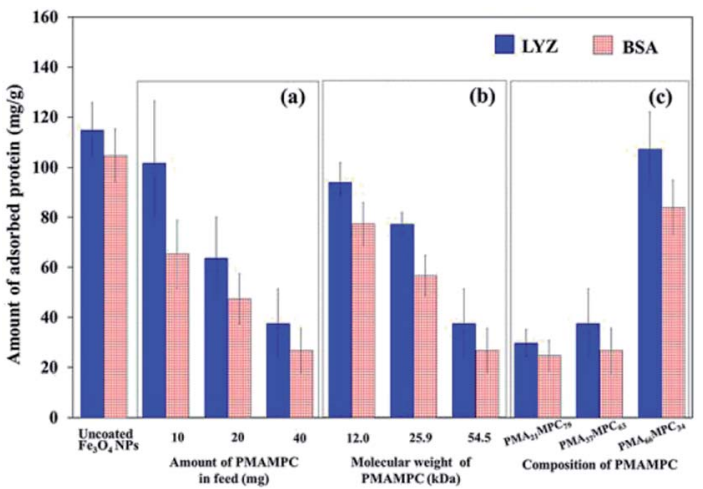

Fig. 4 The amount of adsorbed proteins on PMAMPC- $-\mathrm{Fe}_{3} \mathrm{O}_{4} \mathrm{NPs}$ prepared by the two-step method using (a) varied amount of $\mathrm{PMA}_{37^{-}}$ $M \mathrm{MPC}_{63}$ in feed, (b) varied molecular weight of $\mathrm{PMA}_{37} \mathrm{MPC}_{63}$ and (c) PMAMPC with varied composition.

result was found in both of the increasing polymer chain length and number of MPC units in the copolymer (Fig. 4b and c) in which a greater number of MPC units were obtained. The results strongly suggested that MPC units in the PMAMPC copolymer chain played an important role in preventing protein adsorption. This is in excellent agreement with many reports previously published on the fact that the introduction of MPC units in the copolymer exhibits an outstanding resistance to non-specific interactions with proteins due to its cellmembrane mimic structure. ${ }^{15-22}$

\section{Evaluation of cytotoxicity}

In this research, cytotoxicity of the $\mathrm{Fe}_{3} \mathrm{O}_{4} \mathrm{NPs}$ was evaluated against human umbilical vein endothelial cells (EA.Hy926). As can be seen in Fig. 5, the morphology and growth of cells were not affected by the presence of PMAMPC- $\mathrm{Fe}_{3} \mathrm{O}_{4} \mathrm{NPs}$, implying that the PMAMPC- $\mathrm{Fe}_{3} \mathrm{O}_{4} \mathrm{NPs}$ are biocompatible and not toxic to the cells. The cell-membrane mimic structure of PMPC provides a better environment for cells so that they can maintain their activity and stability. In addition, the PMAMPC- $\mathrm{Fe}_{3} \mathrm{O}_{4} \mathrm{NPs}$ did not seem to attach well to the cell surface as opposed to the uncoated $\mathrm{Fe}_{3} \mathrm{O}_{4} \mathrm{NPs}$ which may be described as a result of the

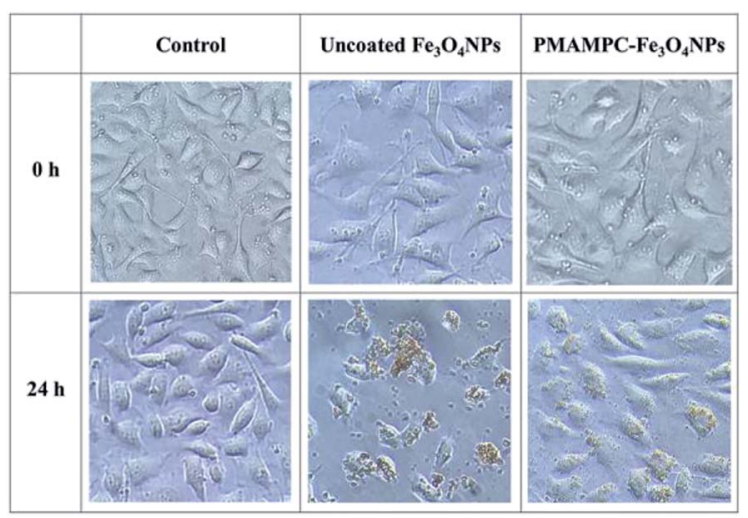

Fig. 5 Morphology of EA.Hy926 cells before and after culturing in the absence (control) and presence of uncoated $\mathrm{Fe}_{3} \mathrm{O}_{4} \mathrm{NPs}$ and PMAMPC$\mathrm{Fe}_{3} \mathrm{O}_{4} \mathrm{NPs}$ at $20 \times$ magnification. 
anti-fouling characteristic of PMPC-based polymer. On the other hand, cells were obviously damaged in the presence of uncoated $\mathrm{Fe}_{3} \mathrm{O}_{4} \mathrm{NPs}$, indicating that they are toxic to the cells. The effect of $\mathrm{Fe}_{3} \mathrm{O}_{4}$ NPs on the cell viability was also evaluated. The results shown in Fig. 6 indicated that PMAMPC- $\mathrm{Fe}_{3} \mathrm{O}_{4} \mathrm{NPS}$ slightly reduced the cell viability (80-84\%) when compared with the control after culturing for $24 \mathrm{~h}$. Interestingly, the cell viability remained almost unchanged when the $\mathrm{Fe}_{3} \mathrm{O}_{4} \mathrm{NPs}$ concentration increased, even at relatively high concentration (up to $0.25 \mathrm{mg} \mathrm{mL}^{-1}$ ). The uncoated $\mathrm{Fe}_{3} \mathrm{O}_{4} \mathrm{NPs}$ caused a significant reduction in cell viability (44-60\%) in a dose-dependent manner. Apparently, the coating of zwitterionic PMAMPC significantly improves the biocompatibility of the $\mathrm{Fe}_{3} \mathrm{O}_{4} \mathrm{NPs}$ as evidenced by the results from cell morphology and the cell viability. This outcome is in good agreement with the work previously reported by Zheng and co-workers ${ }^{\mathbf{1 5}}$ who have demonstrated that the PMAMPC- $\mathrm{Fe}_{3} \mathrm{O}_{4} \mathrm{NPs}$ prepared via the one-step in situ coating of PMAMPC were biocompatible and showed low cell uptake efficiency which correlates well with the high percentage of cell viability.

\section{Biomagnetic separation by PMAMPC-Fe $\mathrm{PO}_{3} \mathrm{NPs}$}

Besides being the anchoring points to the surface of $\mathrm{Fe}_{3} \mathrm{O}_{4} \mathrm{NPs}$, the carboxyl groups of the coated PMAMPC are employed as active sites for attaching amino-functionalized biotin $\left(\mathrm{NH}_{2}\right.$ biotin) via EDC/NHS coupling chemistry. The success of biotin immobilization can be verified by the decrease of the $\mathrm{C}=\mathrm{O}$ stretching peak of the carboxyl groups at $1710 \mathrm{~cm}^{-1}$ in the FTIR spectrum shown in Fig. 1d. The biotinylated PMAMPC$\mathrm{Fe}_{3} \mathrm{O}_{4} \mathrm{NPs}$ were then further tested for specific conjugation with its target molecule, streptavidin. After the conjugation with streptavidin, separation and washing of the biotinylated PMAMPC-Fe $\mathrm{O}_{4} \mathrm{NPs}$ can be easily performed with the aid of a magnet without the requirement for centrifugation. In order to confirm the specificity of biotinylated PMAMPC- $\mathrm{Fe}_{3} \mathrm{O}_{4} \mathrm{NPs}$, the separation of streptavidin was compared with BSA, the non-target molecule (Fig. 7). In the case of streptavidin, the peak at $282 \mathrm{~nm}$ which corresponds to the absorbance of protein chromophores disappeared from the UV-vis spectrum after magnetic separation with biotinylated PMAMPC-

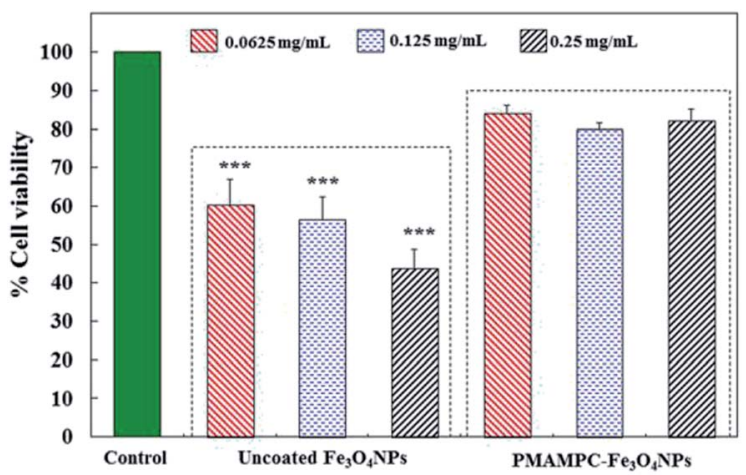

Fig. 6 In vitro cytotoxicity of EA.Hy926 cells before and after culturing for $24 \mathrm{~h}$ in the absence (control) and presence of uncoated $\mathrm{Fe}_{3} \mathrm{O}_{4} \mathrm{NPs}$ and PMAMPC $-\mathrm{Fe}_{3} \mathrm{O}_{4} \mathrm{NPs}$. ${ }^{* * *} p<0.001$ vs. control.
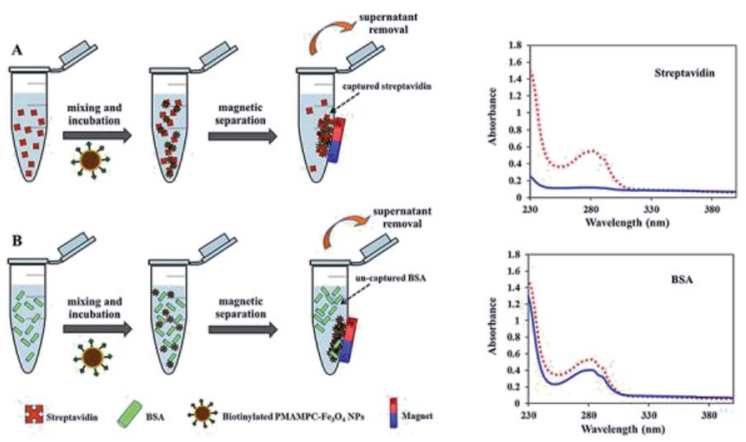

Fig. 7 Schematic representation of the strategy for biomagnetic separation of (A) streptavidin and (B) BSA by biotinylated PMAMPC$\mathrm{Fe}_{3} \mathrm{O}_{4} \mathrm{NPs}$ and their corresponding UV-vis data demonstrating the amount of protein before (red dotted line) and after (blue solid line) magnetic separation.

$\mathrm{Fe}_{3} \mathrm{O}_{4} \mathrm{NPs}$ implying that the streptavidin molecules were captured and entirely removed from the solution. On the other hand, only a slight decrease in intensity of the same peak from the UV-vis spectrum of BSA was observed after magnetic separation with biotinylated PMAMPC- $\mathrm{Fe}_{3} \mathrm{O}_{4} \mathrm{NPs}$. The capture efficiency can be calculated by comparing the concentration of streptavidin or BSA in solution before and after magnetic separation which were found to be $91.5 \%$ and $28.2 \%$, respectively. The results indicate the specificity of the biotinylated PMAMPC- $\mathrm{Fe}_{3} \mathrm{O}_{4} \mathrm{NPs}$ for streptavidin, over BSA. The nonspecific adsorption of the biotinylated PMAMPC- $\mathrm{Fe}_{3} \mathrm{O}_{4} \mathrm{NPs}$ towards BSA corresponds quite well with the data displayed in Fig. 4 in which a nonspecific adsorption of $\mathrm{BSA}$ by the PMAMPC- $\mathrm{Fe}_{3} \mathrm{O}_{4} \mathrm{NPs}$ prepared from $40 \mathrm{mg}$ of $\mathrm{PMA}_{37} \mathrm{MPC}_{63}$, $54.5 \mathrm{kDa}$ was observed. This nonspecific adsorption may be suppressed if blocking of unreacted carboxyl groups is applied after biotin conjugation.

\section{Conclusions}

A simple method for the synthesis of PMAMPC-coated $\mathrm{Fe}_{3} \mathrm{O}_{4}$ NPs by a two-step in situ reaction has been demonstrated. The anchoring of PMAMPC onto the surface of $\mathrm{Fe}_{3} \mathrm{O}_{4} \mathrm{NPs}$ was proven to be through carboxylate chelating interactions. The PMAMPC$\mathrm{Fe}_{3} \mathrm{O}_{4} \mathrm{NPs}$ showed excellent long-term colloidal stability in aqueous media at neutral $\mathrm{pH}$ and their stability was $\mathrm{pH}$ dependent. Despite being coated by the zwitterionic copolymer, the PMAMPC- $\mathrm{Fe}_{3} \mathrm{O}_{4} \mathrm{NPs}$ exhibited a high saturation magnetization value so that they can be easily separated under an external magnetic field without the requirement for centrifugation. The antifouling property of PMAMPC- $\mathrm{Fe}_{3} \mathrm{O}_{4} \mathrm{NPs}$ was found to be dependent on the copolymer content, molecular weight and composition. The coating of zwitterionic PMAMPC can definitely improve biocompatibility of the $\mathrm{Fe}_{3} \mathrm{O}_{4} \mathrm{NPs}$, suggesting that the PMAMPC- $\mathrm{Fe}_{3} \mathrm{O}_{4} \mathrm{NPs}$ may also be further used in contact with cells, for example, as drug carriers. The carboxyl groups in the copolymer coated on the PMAMPC- $\mathrm{Fe}_{3} \mathrm{O}_{4} \mathrm{NPs}$ are readily available for biotin conjugation. The biotinylated PMAMPC- $\mathrm{Fe}_{3} \mathrm{O}_{4} \mathrm{NPs}$ can bind specifically with the target, streptavidin as opposed to the non-specific target, BSA. 


\section{Conflicts of interest}

There are no conflicts to declare.

\section{Acknowledgements}

Financial support was provided by a Research Grant from Burapha University through the National Research Council of Thailand (Grant no. 72/2559) and the Sensor Innovation Research Unit for development and production of test kits, the Center of Excellence for Innovation in Chemistry (PERCH-CIC) and Thailand Research Fund (Grant no. TRG6180133). We thank Prof. Dr Ron Beckett for English proof reading.

\section{References}

1 J. Wan, W. Cai, X. Meng and E. Liu, Chem. Commun., 2007, 5004-5006.

2 A. M. Malekzadeh, A. Ramazani, S. J. T. Rezaei and H. Niknejad, J. Colloid Interface Sci., 2017, 490, 64-73.

3 L. H. Reddy, J. L. Arias, J. Nicolas and P. Couvreur, Chem. Rev., 2012, 112, 5818-5878.

4 Y. Mao, X. Huang, S. Xiong, H. Xu, Z. P. Aguilar and Y. Xiong, Food Control, 2016, 59, 601-608.

5 J.-Y. Hyeon and X. Deng, Food Microbiol., 2017, 63, 111-116.

6 M. Mahmoudi, S. Sant, B. Wang, S. Laurent and T. Sen, Adv. Drug Delivery Rev., 2011, 63, 24-46.

7 S. A. Wahajuddin, Int. J. Nanomed., 2012, 7, 3445.

8 M.-A. Woo, M. I. Kim, J. H. Jung, K. S. Park, T. S. Seo and H. G. Park, Int. J. Mol. Sci., 2013, 14, 9999-10014.

9 Y. Wan, Y. Sun, P. Qi, P. Wang and D. Zhang, Biosens. Bioelectron., 2014, 55, 289-293.

10 S. Shukla, G. Lee, X. Song, S. Park and M. Kim, Biosens. Bioelectron., 2016, 77, 986-994.

11 K. G. Neoh and E. T. Kang, Polym. Chem., 2011, 2, 747-759. 12 S. Wan, Y. Zheng, Y. Liu, H. Yan and K. Liu, J. Mater. Chem., 2005, 15, 3424-3430.

13 S. Wan, J. Huang, H. Yan and K. Liu, J. Mater. Chem., 2006, 16, 298-303.

14 J.-F. Lutz, S. Stiller, A. Hoth, L. Kaufner, U. Pison and R. Cartier, Biomacromolecules, 2006, 7, 3132-3138.
15 C. Zheng, P. Wei, W. Dai, L. Wang, B. Song, P. Jia and Y. Gong, Mater. Sci. Eng., C, 2017, 75, 863-871.

16 F. Dai, M. Zhang, B. Hu, Y. Sun, Q. Tang, M. Du and X. Zhang, RSC Adv., 2015, 5, 3574-3580.

17 K. Ishihara, Y. Fukuda, T. Konno and Y. Inoue, React. Funct. Polym., 2017, 119, 125-133.

18 X. Y. Sun, S. S. Yu, J. Q. Wan and K. Z. Chen, J. Biomed. Mater. Res., Part A, 2013, 101, 607-612.

19 A. K. Peacock, S. I. Cauët, A. Taylor, P. Murray, S. R. Williams, J. V. Weaver, D. J. Adams and M. J. Rosseinsky, Chem. Commun., 2012, 48, 9373-9375.

20 J.-J. Yuan, S. Armes, Y. Takabayashi, K. Prassides, C. Leite, F. Galembeck and A. Lewis, Langmuir, 2006, 22, 1098910993.

21 P. Akkahat, S. Kiatkamjornwong, S.-i. Yusa, V. P. Hoven and Y. Iwasaki, Langmuir, 2012, 28, 5872-5881.

22 O. Wiarachai, T. Vilaivan, Y. Iwasaki and V. P. Hoven, Langmuir, 2016, 32, 1184-1194.

23 I. Serra, R. Fradique, M. Vallejo, T. Correia, S. Miguel and I. Correia, Mater. Sci. Eng., C, 2015, 55, 592-604.

24 K. Srisook, E. Srisook, W. Nachaiyo, M. Chan-In, J. Thongbai, K. Wongyoo, S. Chawsuanthong, K. Wannasri, S. Intasuwan and K. Watcharanawee, J. Ethnopharmacol., 2015, 165, 94102.

25 K. Petcharoen and A. Sirivat, J. Mater. Sci. Eng. B, 2012, 177, 421-427.

26 Q. Li, G. Tang, X. Xiong, Y. Cao, L. Chen, F. Xu and H. Tan, Sens. Actuators, B, 2015, 215, 86-92.

27 G. Deacon and R. Phillips, Coord. Chem. Rev., 1980, 33, 227250.

28 M. Mahdavi, M. B. Ahmad, M. J. Haron, F. Namvar, B. Nadi, M. Z. A. Rahman and J. Amin, Molecules, 2013, 18, 75337548.

29 G. Wang, X. Zhang, A. Skallberg, Y. Liu, Z. Hu, X. Mei and K. Uvdal, Nanoscale, 2014, 6, 2953-2963.

30 Q. Lu, D. Wei, J. Zhou, J. Xu, J. Cheng and J. Zhu, Chin. J. Chem., 2013, 31, 401-406.

31 M. I. Majeed, J. Guo, W. Yan and B. Tan, Polymers, 2016, 8, 392-408.

32 B. D. Cullity, Elements of X-ray Diffraction, Addison-Wesley Publishing Company, Reading, MA, 1978. 